\title{
Interaction between odontoblast and bio-calcium phosphate cement reinforced with chitosan
}

\author{
Byung-Do Chun', Sung-Won Kim¹, Sung-Tak Lee', Tae-Hoon Kim¹, Jung-Han Lee', \\ Gyoo-Cheon Kim², Yong-Deok Kim¹, Uk-Kyu Kim¹ \\ 'Department of Oral and Maxillofacial Surgery, 'Department of Oral Anatomy, \\ School of Dentistry, Pusan National University, Yangsan, Korea
}

\begin{abstract}
J Korean Assoc Oral Maxillofac Surg 2011;37:415-20)
Purpose: Calcium phosphate cement (CPC) is one of many useful materials for restoring tooth defects, periodontium and maxillofacial area. Chitosan is a biodegradable material that has been shown to promote the growth and differentiation of osteoblasts in culture. This study examined the interaction between odontoblasts and bio-calcium phosphate cement reinforced with chitosan.

Materials and Methods: $5 \times 10^{3}$ odontoblastic cells were seeded into each well. Various concentrations of bio-calcium phosphate cement reinforced with chitosan $(10,20,50,100,200,500 \mu \mathrm{g} / \mathrm{ml}, 1,2,4 \mathrm{mg} / \mathrm{ml})$ were diluted and added to the wells. The well was incubated for $24 \mathrm{~h}, 48 \mathrm{~h}$ and $72 \mathrm{~h}$. After incubation, the number of cells was assessed to determine the cell viability. A cytokinesis-block micronucleus assay and chromosomal aberration test were carried out to estimate the extent of chromosomal abnormalities. Microscopic photographs and RT-PCR were performed to examine the adhesion potential of bio-calcium phosphate cement reinforced with chitosan.

Results: Bio-CPC-reinforced chitosan did not show significant cytotoxicity. The number of damaged chromosomes in the cells treated with BioCPC-reinforced chitosan was similar to that in the control cells. There was no significant increase in the number of chromosomal aberrations in the Bio-CPC reinforced chitosan exposed cells. Microscopic photographs and RT-PCR confirmed the adhesive potential of bio-CPC reinforced chitosan to odontoblasts.

Conclusion: Bio-CPC-reinforced chitosan did not affect the odontoblastic cell viability, and had no significant cytotoxic effect. Bio-CPC-reinforced chitosan showed adhesive potential to odontoblasts. These results are expected form the basis of future studies on the effectiveness of dental restorative materials in Bio-CPC reinforced with chitosan.
\end{abstract}

Key words: Calcium phosphate cement, Chitosan, Odontoblast

[paper submitted 2011. 3. 3 / revised 2011. 8. 30 / accepted 2011. 9. 29]

\section{I . Introduction}

Tooth is one of the most typical tissue that is not regenerated if its structure is destructed once in human's body. In addition, materials we used for damaged tooth are just replace the tooth structure, not related with substances consisting tooth. To regenerate tooth structure, materials should have ability to remineralize damaged portion. So many materials were investigated to restore destructed tooth structure.

One of useful materials to restore tooth defect is calcium phosphate cement (CPC). CPC is a well-known synthetic bone graft material. In dental area, CPC is used for pulp-capping material alternative to calcium hydroxide $(\mathrm{CH})$. Traditionally, different formulations of calcium hydroxide $(\mathrm{CH})$ have been

\section{김 욱 규}

626-770 경상남도 양산시 물금읍 범어리

부산대학교 치의학전문대학원 구강악안면외과

Uk-Kyu Kim

Department of Oral and Maxillofacial Surgery, School of Dentistry,

Pusan National university

Beomeo-ri, Mulgeum-eup, Yangsan, 626-770, Korea

TEL: +82-55-360-5100 FAX: +82-55-360-5104

E-mail:kuksjs@pusan.ac.kr used for conservative pulp therapy ${ }^{1}$. However, there are disadvantages associated with the use of $\mathrm{CH}$, such as the presence of tunnels in the dentin bridge and the lack of adhesion and degradation after acid etching. $\mathrm{CPC}$ is superior to pure $\mathrm{CH}$, which means that this material may have applications in pulp capping to induce reparative dentin formation or as a lining material ${ }^{2}$. But, $\mathrm{CPC}$ is fabricated at $1500^{\circ} \mathrm{C}$ and pulverized. The frozen phase is not dissolved at $37^{\circ} \mathrm{C}$. Thus, powder size is issue for cement reaction. Biomimetic calcium phosphate cement (Bio-CPC), in contrast, is made at $37^{\circ} \mathrm{C}$, and it can be paste phase in $37^{\circ} \mathrm{C}$. It is expected better properties than previous CPC.

Chitosan and chitosan derivatives appear to be good candidates for the elastomeric matrix. These natural biopolymers are biocompatible and biodegradable ${ }^{3}$, and osteoconductive ${ }^{4}$. They have been used in surgical interventions for the reduction of periodontal pockets ${ }^{5}$ in dental area. Chitosan has also been studied in vitro and in vivo with calcium phosphate compounds. Recently, chitosan/hydroxyapatite composites have been prepared with a homogeneous nanostructure using a coprecipitation method ${ }^{6}$. 
The aim of this study was to find basis on effectiveness of the Bio-CPC reinforced with chitosan. To investigate biological effects such as cell viability, cell proliferation, differentiation and adhesive potential of Bio-CPC reinforced with chitosan on odontoblast, interaction between Bio-CPC reinforced with chitosan and odontoblast.

\section{Materials and Methods}

Cell culture

We used the MDPC-23 mouse odontoblast-like cell. The cells were cultured in cell culture media (Dulbecco's modified Eagles medium, Gibco, NY, USA) supplemented with $10 \%$ heat-inactivated serum (fetal bovine serum (FBS), GIBCO) and $100 \mu \mathrm{g} / \mathrm{ml}$ penicillin/ streptomycin at $37^{\circ} \mathrm{C}$ in humidified incubator with $5 \% \mathrm{CO}_{2}$ atmosphere.

The effect of CPC-ch powders on MDPC-cell viability

$5 \times 10^{3}$ cells were seeded into each well of 96-well tissue culture plate and incubated for $24 \mathrm{~h}$. The Powdered Bio-CPC reinforced chitosan was diluted in growth media. Each media was incubated for $24 \mathrm{~h}, 48 \mathrm{~h}$ and $72 \mathrm{~h}$. After incubation, $10 \mu \mathrm{l}$ of WST-1 solution was added to each well. Then incubating for $30 \mathrm{~min}$, transfer $80 \mu \mathrm{l}$ of solution to new plate and measure the O.D at $450 \mathrm{~nm}$ wavelength. For the control, $100 \mu$ of Bio-CPC reinforced chitosan-diluted media was incubated for $24 \mathrm{~h}$ (without cells), and used for WST-1 assay.

\section{Cytokinesis-block micronucleus assay}

The MDPC 23 cells were seeded into a $100 \mathrm{~mm}$ dish at a density of $1 \times 10^{6} /$ well and incubated for $20 \mathrm{~h}$. The cells were treated with Bio-CPC reinforced chitosan $(100 \mu \mathrm{g} / \mathrm{ml})$ for $24 \mathrm{~h}$. Cytochalasin B $(3 \mu \mathrm{g} / \mathrm{ml})$ was added $44 \mathrm{~h}$ after the start of the culture, and incubation was continued for an additional $28 \mathrm{~h}$. After culturing for $72 \mathrm{~h}$, the cells were harvested and incubated in PBS for $5 \mathrm{~min}$. After fixing carnoy solution (a mixture of methanol and acetic acid; $3: 1$ ) for $20 \mathrm{~min}$ at $4{ }^{\circ} \mathrm{C}$. The cell solution was dropped onto cold glass slides. Air-dried cell preparations were stained with $8 \%$ Giemsa solution for $15 \mathrm{~min}$.

\section{Chromosomal aberration test}

The CHO-k1 cells were seeded into a $100 \mathrm{~mm}$ dish at a density of $1 \times 10^{6} /$ well and incubated for $24 \mathrm{~h}$. The cells were treated with Bio-CPC reinforced chitosan $(100 \mu \mathrm{g} / \mathrm{ml})$ for $24 \mathrm{~h}$.
Added Colchicine was a final concentration of $4 \mu \mathrm{g} / \mathrm{ml}$ and incubated for $2 \mathrm{~h}$. After the cells were harvested and incubated in $0.075 \mathrm{M} \mathrm{KCL}$ for $20 \mathrm{~min}$ at $37^{\circ} \mathrm{C}$. After fixing carnoy solution for $20 \mathrm{~min}$ for $4^{\circ} \mathrm{C}$. The cell solution was dropped onto cold glass slides. Air-dried cell preparations were stained with $8 \%$ Giemsa solution for $15 \mathrm{~min}$.

\section{Adhesion of Cells to CPC powders}

$3 \times 10^{5}$ cells on each well were seeded into 6-well plates.(coated, or non-coated with adhesion molecules) At the same time, $1 \mathrm{mg} / \mathrm{ml}$ Bio-CPC reinforced chitosan powders was added to non-coated plate for experimental group. After $24 \mathrm{~h}$ of incubation, microscopic photographs were taken and then cells were gathered, and subjected to RNA extraction procedure using Trizol reagent. $1 \mu \mathrm{g}$ of extracted total RNA was used for cDNA synthesis. $3 \mu$ of each cDNA was used for PCR against adhesion proteins and functional markers.

\section{Total RNA extraction, RT-PCR}

Total RNA was extracted from each sample using the Trizol reagents (Invitrogen) according to the manufacturer's instructions and treated with DNase I (Promega, Madison, WI, USA). First strand complementary DNA (cDNA) was reverse transcribed using the Reverse transciption kit(Maxime RT PreMix kit, iNtRON, Daejon, Korea). The PCR products were resolved by electrophoresis on $1.5 \%$ ethidium bromide stained agarose gel. Detailed information of primers used in this article was subscribed on Table 1.

Table 1. Reverse transcriptase-polymerase chain reaction (RT-PCR) primers sequence

\begin{tabular}{llr}
\hline Gene name & \multicolumn{1}{c}{ Sequence } & $\begin{array}{c}\text { Product } \\
\text { size }\end{array}$ \\
\hline $\begin{array}{l}\text { Alkaline } \\
\text { Phosphatase-1 }\end{array}$ & $\begin{array}{l}\text { TTTGGTGGATACACCCCC } \\
\text { Integrin } \beta 1\end{array}$ & $176 \mathrm{bp}$ \\
& $\begin{array}{l}\text { TACACTGGTAGTTGTTGTGAGC } \\
\text { CTCTGCACTGAACACATTCT }\end{array}$ & \\
Integrin $\alpha 1$ & GGAGCTGTGTACATTTATCA & $303 \mathrm{bp}$ \\
& TGTAGCATTTATGCATACTG & \\
Integrin $\alpha 2$ & TTTGGTTCAGCAATTGCA & $238 \mathrm{bp}$ \\
& TGGAATCCCCATTTAAATC & \\
CD 44 & AGAAGGTGTGGGCAGAAG & $203 \mathrm{bp}$ \\
$\beta$-actin & CCAATCTTCATGTCCACA & \\
& $\begin{array}{l}\text { GACTACCTCATGAAGATC } \\
\text { Byung-Do Chun et al: Interaction between odontoblast and bio-calcium phosphate } \\
\text { cement reinforced with chitosan. } J \text { Korean Assoc Oral Maxillofac Surg 2011 }\end{array}$
\end{tabular}




\section{Results}

Effects of cements on cell toxicity

Cell numbers assessed using Cell Proliferation Reagent WST-1, were represented in Figure 1. It was observed that all concentration of powdered Bio-CPC reinforced chitosan we studied in $24 \mathrm{~h}$ incubation has cytotoxicity against MDPC-23 cells. At $48 \mathrm{~h}$ after treatment, in contrast, Bio-CPC reinforced

A

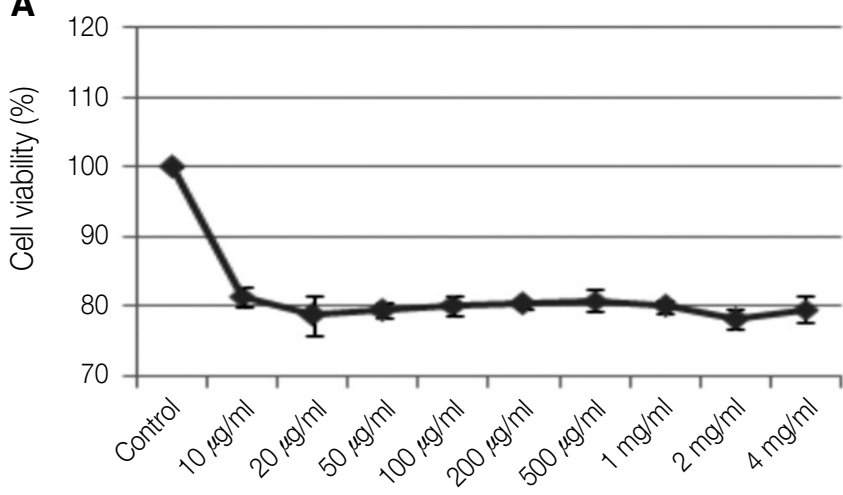

B

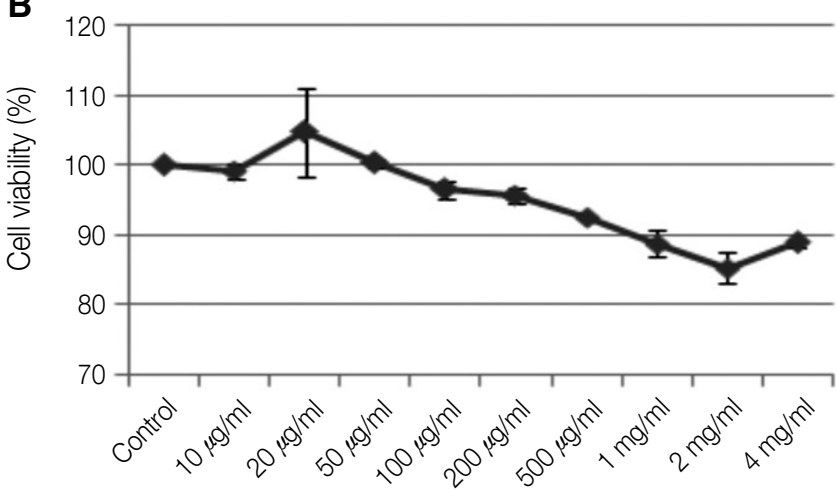

C

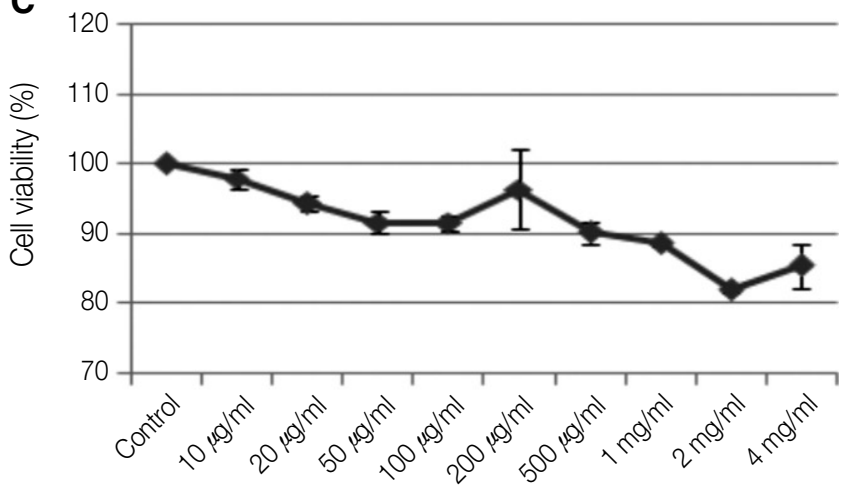

Fig. 1. The effects of cements on cell viability.

Byung-Do Chun et al: Interaction between odontoblast and bio-calcium phosphate cement reinforced with chitosan. J Korean Assoc Oral Maxillofac Surg 2011 chitosan did not show significant cytotoxicity, especially it accelerated cell proliferation in $50 \mu \mathrm{g} / \mathrm{ml}$. After $72 \mathrm{~h}$, it didn't shows cytotoxicity significantly.

\section{Cytokinesis-block micronucleus assay}

The assay was performed in $100 \mu \mathrm{g} / \mathrm{ml}$, beacause it was the concentration not disturbing for proliferation of MDPC23 cells. The numbers of damaged chromosomes in the cells treated with Bio-CPC reinforced chitosan were similar with in control cells.(Fig. 2) Total number of micronuclei (MN) in binucleated $(\mathrm{BN})$ cells were similar with control group (5 in treated with CPC-ch, 3 in control group). But Other DNA damage events such as nucleoplasmic bridges (NPB) or nuclear buds (NBUD) were not shown in the present study. There was no $\mathrm{BN}$ cells with NPB in CPC-ch, $1 \mathrm{BN}$ cell found in control group in contrast.

\section{Chromosomal aberration test}

There was no significant increase in chromosomal aberration in Bio-CPC reinforced chitosan treatment $(100 \mu \mathrm{g} / \mathrm{ml})$ compared with the control group.(Fig. 3) In chromatid level, 2 chromatid break (ctb) were found in Bio-CPC reinforced chitosan. Chromatid exchange (cte) was not seen. In chromosomal change, 3 chromosome break (csb) were shown in CPC-ch and no chromosome exchange (cse) was found. In control group, $4 \mathrm{csb}$ and $5 \mathrm{cse}$ were observed, but any other structural aberrations in chromatid level was not seen.

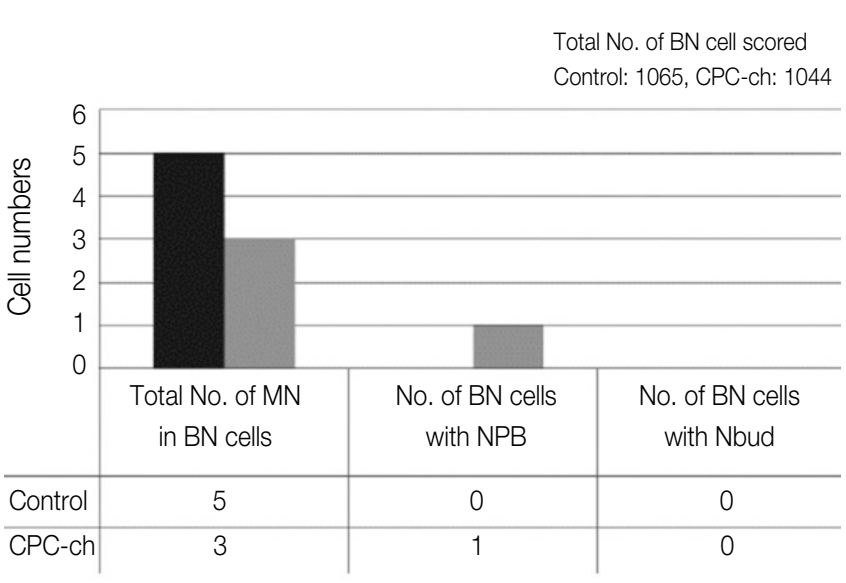

Fig. 2. Cytokinesis-block micronucleus assay.

Byung-Do Chun et al: Interaction between odontoblast and bio-calcium phosphate cement reinforced with chitosan. J Korean Assoc Oral Maxillofac Surg 2011 


\begin{tabular}{|c|c|c|c|c|c|c|c|c|c|}
\hline \multirow{3}{*}{ Treatment } & \multirow{3}{*}{$\begin{array}{c}\text { Time of } \\
\text { treatment (h) }\end{array}$} & \multirow{3}{*}{$\begin{array}{l}\text { Concentration of } \\
\text { treatment }(\mu \mathrm{g} / \mathrm{mL})\end{array}$} & \multirow{3}{*}{$\begin{array}{c}\text { Chromosome } \\
\text { NO. }\end{array}$} & \multicolumn{6}{|c|}{ NO. of chromosmal structure abnormality } \\
\hline & & & & \multirow{2}{*}{$\frac{\text { Gap }}{g}$} & \multicolumn{2}{|c|}{ Chromatid } & \multicolumn{2}{|c|}{ Chromosome } & Etc. \\
\hline & & & & & ctb & cte & csb & cse & \\
\hline Control & - & - & 1072 & 0 & 0 & 0 & 4 & 5 & 0 \\
\hline CPC-ch & 24 & 100 & 1152 & 0 & 2 & 0 & 3 & 0 & 0 \\
\hline
\end{tabular}

Fig. 3. Chromosomal abberration test.

Byung-Do Chun et al: Interaction between odontoblast and bio-calcium phosphate cement reinforced with chitosan. J Korean Assoc Oral Maxillofac Surg 2011

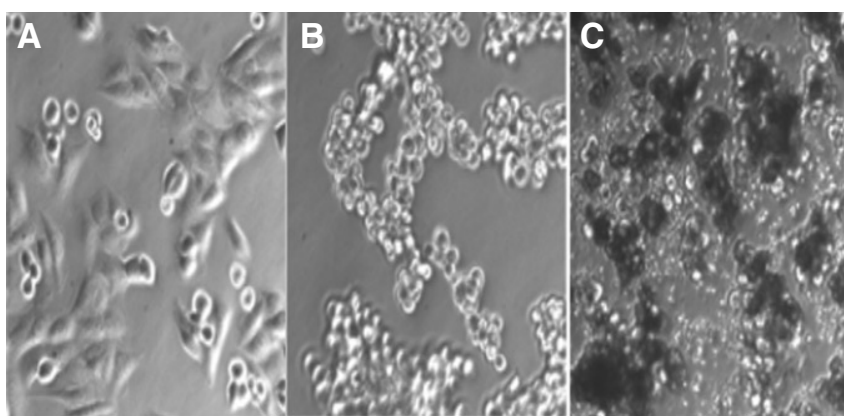

Fig. 4. Microscopic photography of the cell adhesion. A: coated plate, B: non-coated plate, C: non-coated plate with CPC-ch.

Byung-Do Chun et al: Interaction between odontoblast and bio-calcium phosphate cement reinforced with chitosan. J Korean Assoc Oral Maxillofac Surg 2011

Adhesion of cells to CPC powders \& total RNA extraction, RT-PCR

The assay was also performed in $100 \mu \mathrm{g} / \mathrm{ml}$ concentration. Figure 4 shows the microscopic morphologies of cell adhesion on each well. In this study, cells in coated plate/non-coated plate were used as a positive/negative control. In coated plate, the cells sticked to adhesion molecules, whereas cells didn't in non-coated plate. In non-coated plate with Bio-CPC reinforced chitosan, cells were located around powder. Expression of Alkaline Phosphatase-1, Integrin $\beta 1$, Integrin $\alpha 1$, Integrin $\alpha 2$, CD 44 , and $\beta$-actin messenger RNA in cells on each sample was shown in Figure 5. In non-coated plate, cells expressed various adhesional molecules in order to adhere to something. But in non-coated plate with Bio-CPC reinforced chitosan, the expression of mRNAs was similar to that of cells in coated plate rather than non-coated plate's.

\section{Discussion}

Calcium phosphate cement (CPC) is a synthetic bone graft material that was invented in 1986 by Chow and Brown, scientists at the American Dental Association. The cement is a white powder consisting of equimolar amounts of ground

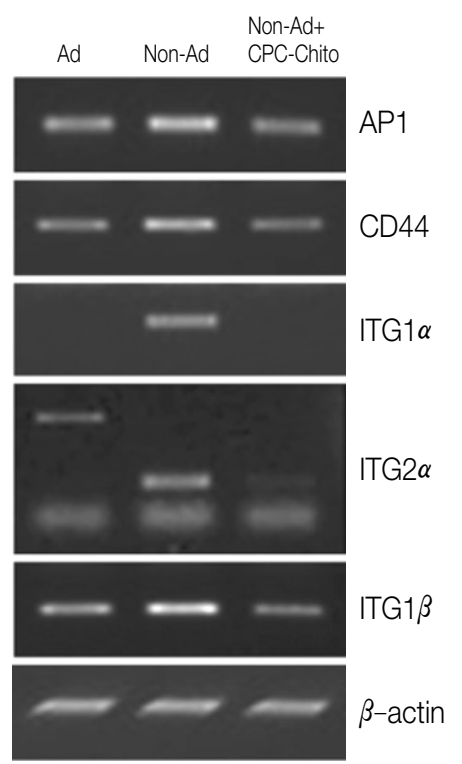

Fig. 5. The expression of mRNAs in MDPC-23 cells. Byung-Do Chun et al: Interaction between odontoblast and bio-calcium phosphate cement reinforced with chitosan. J Korean Assoc Oral Maxillofac Surg 2011

$\mathrm{Ca}_{4}\left(\mathrm{PO}_{4}\right)_{2} \mathrm{O}$ (tetracalcium phosphate, TTCP) and $\mathrm{CaHPO}_{4}$ (dicalcium phosphate anhydrous, DCPA). When mixed with water, the material forms a workable paste which can be shaped during surgery to fit the contours of bone defects. The cement hardens within $20 \mathrm{~min}$ allowing rapid closure of the wound. The hardening reaction, which forms nanocrystalline hydroxyapatite (HA) as the product, is isothermic and occurs at physiologic $\mathrm{pH}$ so tissue damage does not occur during the setting reaction.

Hydroxyapatite is an important biomaterial because of its similarity to the apatitic mineral in natural teeth and bones ${ }^{7,8}$ CPC was developed with the advantage of being moldable and capable of in situ setting to form hydroxyapatite ${ }^{9}$. Several different cement compositionswere developed. The CPC powder consisted of TTCP and DCPA, when mixed with water at a powder:liquid ratio of $4: 1$, the paste hardened in about $30 \mathrm{~min}$ and formed hydroxyapatite ${ }^{9-11}$. CPC showed excellent biocompatibility and osteoconductivity, and was able to be resorbed and replaced by new bone ${ }^{10,11}$. It was approved in 1996 by the Food and Drug Administration for repairing craniofacial defects in humans, thus 
becoming the first $\mathrm{CPC}$ available for clinical use ${ }^{11}$.

CPC showed promise for several dental applications, including root canal filler, sealer ${ }^{12,13}$ and base applications ${ }^{14}$. CPC-containing dental composites were also developed ${ }^{15}$. Unlike traditional composites with glassy fillers, the CPC powder as fillers in resins resulted in the release of $\mathrm{Ca}$ and $\mathrm{PO}_{4}$ ions. These composites showed potential for pulp capping and cavity lining applications, and remineralized in vitro the demineralized dentin.

Recently, CPC has been also combined with a biopolymer chitosan to yield a strong and non-rigid hydroxyapatite composite envisioned for periodontal bone repair ${ }^{16-18}$. Chitosan is frequently proposed in the research field of tissue engineering ${ }^{19-21}$. This deacetylated derivative of chitin commonly found in shells of marine crustaceans and fungi is a linear polysaccharide, composed of glucosamine and $\mathrm{N}$-acetyl glucosamine linked in a (1-4) manner. The glucosamine/ $\mathrm{N}$-acetyl glucosamine ratio is referred as the degree of de-acetylation, which can vary from $30 \%$ to $95 \%$. In its crystalline form, chitosan is normally insoluble in aqueous solutions above $\mathrm{pH} 7$; however in dilute acids $(\mathrm{pH}<6.0)$, the protonated free amino groups on glucosamine facilitate solubility of the molecule. Chitosan is biodegradable, and has been shown to promote the growth and differentiation of osteoblasts in culture. It can be molded in porous structures and has been used in association with other biomaterials ${ }^{22}$ such as CPC. CPC set in situ to form hydroxyapatite are promising materials for a wide range of clinical applications especially in bone reconstruction due to their good osteoconductivity. Several groups have shown that chitosan can be used as adjuvant to $\mathrm{CPC}$ in order to enhance their mechanical properties without altering their chemical properties ${ }^{23}$.

But previous CPC has some limitation. The tetracalcium phosphate powder was formed from a solid-state reaction between equimolar amounts of DCPA and $\mathrm{CaCO}_{3}$, which were mixed and heated at $1500^{\circ} \mathrm{C}$. The frozen phase of $\mathrm{CPC}$ is not well dissolved at $37^{\circ} \mathrm{C}$. So powder size is an important issue for cement reaction and application of $\mathrm{CPC}$ needs water. On the other hand, Bio-CPC is produced at $37^{\circ} \mathrm{C}, 10.5<\mathrm{pH}<12.0$, it is confirmed through X-ray diffraction. It can be paste phase at $37^{\circ} \mathrm{C}$. No water for disolving $\mathrm{CPC}$ was needed, thus BioCPC may have resistance for resorption. Bio-CPC may be a polymeric molecular structure of TTCP, HA and $\mathrm{Ca}(\mathrm{OH})_{2}$. Bio-CPC is mixed with a small amount of DCPA, HA formed. Bio-CPC The amount of DAPA for the reaction depends on the Bio-CPC paste at from 11.6 to 11.7 in $\mathrm{pH}$ for suspension and emulsion, respectively. Bio-CPC may be used for bone cements because it makes HA like CPC. In this study, BioCPC is used because of this advantage. Addition of chitosan, enhanced the mechanical and biological properties of material.
Further studies are needed to investigate biocompatibility of biomimetic TTCP.

I tested the experimental Bio-CPC reinforced chitosan for their effects on MDPC-23 proliferation and odontogenesis. I found that Bio-CPC reinforced chitosan were cytotoxic for MDPC-23 at $24 \mathrm{~h}$ of cultivation. These results are supported by the data of Khashaba et al. ${ }^{24}$ who reported that CPC decreased the proliferation of human gingival fibroblasts and a mouse fibroblast cell line. In the CPC setting, TTCP and DCPA dissolved in the liquid as $\mathrm{Ca}^{2+}, \mathrm{PO}_{4}{ }^{3-}$, and $\mathrm{OH}$-ions, which then reprecipitated to form hydroxyapatite ${ }^{25}$. It seems likely that the ionic activities and $\mathrm{pH}$ changes that occurred during setting were responsible for the observed cytotoxicities $^{26}$. But relative cell viability showed over $80 \%$ at all concentrations in $24 \mathrm{~h}$. Besides in $48 \mathrm{~h}$ and $72 \mathrm{~h}$, it showed over $90 \%$ of control group and some showed over $100 \%$. For chromosomal abberration, Bio-CPC reinforced chitosan also have good nature. In this study, only few cells were shown abnomalities in Bio-CPC reinforced chitosan group. Lee et al.(2010) studied toxicity of CPC to the human dental pulp cells.27 The results showed CPC decreased viability of cells but it's not critical. They also showed CPC containing chitosan was less toxic to the cells. In this respect, Bio-CPC reinforced chitosan didn't seemed to have cytotoxicities.

Reverse transcription polymerase chain reaction (RT-PCR) is widely used in the diagnosis of genetic diseases and, semiquantitatively, in the determination of the abundance of specific different RNA molecules within a cell or tissue as a measure of gene expression. In this study, RT-PCR was used to check expression of adhesion molecules. In non-coated plate with Bio-CPC reinforced chitosan powders (experimental group), several adhesion molecules were expressed like coated plate (positive control). Cell adhesion is important for bonding between dentin and Bio-CPC reinforced chitosan, the results shows Bio-CPC reinforced chitosan can be used for restorative material. In non-coated plate with Bio-CPC reinforced chitosan, the expression of mRNAs was similar to that of cells in coated plate rather than non-coated plate's. The expression of AP1, CD44, ITG $\beta 1$ and $\beta$-actin in experimental group was similar to positive control, besides ITG $\alpha 2$ expression was less than coated plate. ITG $1 \alpha$ expression was found in negative control group, but experimental group and positive control group were not shown neither. It means Bio-CPC reinforced chitosan have good adhesive potential to odontoblast.

Thus, Bio-CPC reinforced chitosan is a good potential material to restore dental tissue. Further studies are needed to the effectiveness of dental restorative material in Bio-CPC reinforced chitosan. 


\section{Conclusion}

Biomimetic calcium phosphate cement can be widely used to endodontic, periodontal and oral and maxillofacial area. Chitosan is useful for medical treatment by its biocompatibility and osteoconductibility. It was tested that interaction between Bio-CPC reinforced chitosan and odontoblast to investigate cell viability, adhesive potential and cytotoxicity of Bio-CPC.

In order to test the effect of Bio-CPC reinforced chitosan powders on MDPC-cell viability, cytokinesis-block micronucleus assay, chromosomal aberration test, adhesion of cells to powders and total RNA extraction, RT-PCR were performed. In cell viability test, mild decreased MDPC-23 cells were shown after $24 \mathrm{~h}$ incubation with Bio-CPC reinforced chitosan. But in $48 \mathrm{~h}$ and $72 \mathrm{~h}$ incubation, Bio-CPC reinforeced chitosan didn't affect cell viability significantly. And chromosmal abberration was not occurred by Bio-CPC reinfored chitosan. In adhesive potential, it was shown that odontoblast attached around Bio-CPC reinforced chitosan. Also, the adhesive molecules were expressed similar to that of cells in coated plate in non-coated plate with Bio-CPC reinforced chitosan.

In conclusion,

1. Bio-CPC reinforced chitosan did not affect odontoblastic cell viability.

2. Bio-CPC reinforced chitosan did not show any remarkable cytotoxic effect .

3. Bio-CPC reinforced chitosan showed adhesive potential to odontoblast.

These results will form the basis of future studies on the effectiveness of dental restorative material in Bio-CPC reinforced with chitosan.

\section{References}

1. Pereira JC, Segala AD, Costa CAS. Human pulpal response to direct pulp capping with an adhesive system. Am J Dent 2000; 13:139-47.

2. Cox CF, Hafez AA, Akimoto N, et al. Biocompatibility of primer, adhesive and resin composite systems on non-exposed and exposed pulps of non-human primate teeth. Am J Dent 1998; 11:S55-63.

3. Machida Y, Nagai T, Abe M, Sannan T. Use of chitosan and hydroxypropylchitosan in drug formulations to effect sustained release. Drug Dis Deliv 1986;1:119-30.

4. Muzzarelli RAA, Biagini G, Bellardini M, Simonelli L, Castaldini C, Fratto G. Osteoconduction exerted by methylpyrrolidinone chitosan used in dental surgery. Biomaterials 1993; 14(1):39-43.

5. Muzzarelli RAA. Amphoteric derivatives of chitosan and their biological significance. In: Skjak-Brak G, Anthonsen T, Sandford P, editors. Chitin and chitosan. New York: Elsevier; 1989. p. 87-99.

6. Yamaguchi I, Tokuchi K, Fukuzaki H, Koyama Y, Takakuda K, Monma H, Tanaka J. Precipitation and microstructure analysis of chitosan/hydroxyapatite nanocomposites. J Biomed Mater Res 2001;55:20-7.

7. LeGeros RZ. Biodegradation and bioresorption of calcium phosphate ceramics. Clin Mater 1993;14:65-88.

8. Chang MC, Ko CC, Douglas WH. Preparation of hydroxyapatitegelatin nanocomposites. Biomaterials 2003;24:2853-62.

9. Brown WE, Chow LC. A new calcium phosphate water setting cement. In: Brown PW, editor. Cements research progress. Westerville, OH: Am. Ceram. Soc.; 1986. p. 352-79.

10. Shindo ML, Contantino PD, Friedman CD, Chow LC. Facial skeletal augmentation using hydroxyapatite cement. Arch Otolaryngol Head Neck Surg 1993;119:185-90.

11. Friedman CD, Costantino PD, Takagi S, Chow LC. BoneSourceTM hydroxyapatite cement: a novel biomaterial for craniofacial skeletal tissue engineering and reconstruction. J Biomed Mater Res 1998;43B:428-32.

12. Sugawara A, Kusama K, Nishimura S, Nishiyama M, Moro I, Kudo I, et al. Histopathological reaction of a calcium phosphate cement root canal filler. J Hard Tissue Biol 1995;4:1-7.

13. Cherng AM, Chow LC, Takagi S. In vitro evaluation of a calcium phosphate cement root canal filler/sealer. J Endodontics 2001;27:613-5.

14. Dickens-Venz SH, Takagi S, Chow LC, Bowen RL, Johnston AD, Dickens B. Physical and chemical properties of resin-reinforced calcium phosphate cements. Dent Mater 1994;10:100-6.

15. Dickens SH, Flaim GM, Takagi S. Mechanical properties and biochemical activity of remineralizing resin-based a-PO4 cements. Dent Mater 2003;19:558-66.

16. Takagi S, Chow LC, Hirayama S, Eichmiller FC. Properties of novel resorbable chitosan-calcium phosphate composites. Dent Mater 2003;19:797-804.

17. Xu HHK, Quinn JB, Takagi S, Chow LC. Synergistic reinforcement of in situ hardening calcium phosphate composite scaffold for bone tissue engineering. Biomaterials 2004;25:1029-37.

18. Xu HHK, Simon Jr CG. Fast setting calcium phosphate-chitosan scaffold: mechanical properties and biocompatibility. Biomaterials 2005;26:1337-48.

19. Di Martino A, Sittinger M, Risbud MV. Chitosan: a versatile biopolymer for orthopaedic tissue-engineering. Biomaterials 2005;26:5983-90.

20. Prabaharan M. Review paper: chitosan derivatives as promising materials for controlled drug delivery. J Biomater Appl 2008;23: $5-36$.

21. Kim IY, Seo SJ, Moon HS, Yoo MK, Park IY, Kim BC, et al. Chitosan and its derivatives for tissue engineering applications. Biotechnol Adv 2008;26:1-21.

22. Li X, Feng Q, Liu X, DongW, Cui F. Collagen-based implants reinforced by chitin fibres in a goat shank bone defect model. Biomaterials 2006;27:1917-23.

23. Padois K, Rodriguez F. Effects of chitosan addition to self-setting bone cement. Biomed Mater Eng 2007;17:309-20.

24. Khashaba RM, Chutkan NB, Borke JL. Comparative study of biocompatibility of newly developed calcium phosphate-based root canal sealers on fibroblasts derived from primary human gingiva and a mouse L929 cell line. Int Endod J 2009;42:711-8.

25. Dagang G, Kewei X, Haoliang S, et al. Physicochemical properties of TTCP/DCPA system cement formed in physiological saline solution and its cytotoxicity. J Biomed Mater Res A 2006; 77:313-23.

26. Matsuya $\mathrm{S}$, Takagi $\mathrm{S}$, Chow LC. Effect of mixing ratio and $\mathrm{pH}$ on the reaction between $\mathrm{Ca}_{4}\left(\mathrm{PO}_{4}\right)_{2} \mathrm{O}$ and $\mathrm{CaHPO}_{4}$. J Mater Sci Mater Med 2000;11:305-11.

27. Sun-Kyung Lee, Sang-Kwang Lee, Sang-Im Lee, Jeong-Hui Park, Jun-Hyeog Jang, Hae-Won Kim, Eun-Cheol Kim. Effect of Calcium Phosphate Cements on Growth and Odontoblastic Differentiation in Human Dental Pulp Cell. Journal of Endodontics, 2010;36(9):1537-42. 